\title{
2 宇宙機のセンサ技術
}

\section{1.まえがき}

人工衛星, 惑星探査機, 探査ロボットなど (総称して宇 宙機と呼ぶ）は，地上からコンタクトできない非可視時間 がある，通信容量に制限がある，惑星探査機などでは電波 伝搬遅延があるなどの理由から, 機上での自動化自律化機 能が必須となっている. 特に電力的, 熱的条件, あるいは ミッション要求 (地球観測, 天文観測, 通信など) から, 宇 宙機の姿勢は搭載センサにより検出し，搭載計算機により 自動制御しているのが通常である，位置については，従来 は主に地上からの電波による距離・速度計測により軌道決 定をしていたが，最近では人工衛星にGPS受信機を搭載し て機上で自分の位置を計測することにより運用コスト低減 や自律性向上を図ったり, 惑星探査機では搭載カメラの画 像を用いることにより地上からの測距よりも高精度に位置 決定をする方法が研究されている。

これらの位置・姿勢を知るための搭載センサはそれぞれ 特徵があり, 宇宙機はこれらを場合に応じて使い分け, 組 合せて使用している。本稿では，宇宙機に使われる姿勢・ 位置検出用のセンサについて紹介し, それらのデー夕の複 合利用法について概説する。

\section{2. 宇宙機の姿勢検出センサ}

人工衛星, 惑星探査機には, そのミッション要求に応じ ていくつかの種類のセンサが搭載されている。その検出す る物理量の観点から分類すると，以下のように分けられる.

\section{1 慣性座標に対する相対姿勢変化を検出するもの}

いわゆる慣性基準装置 (Inertial Reference Unit：IRU) と呼ばれるもので, 宇宙機搭載用には機械式ジャイロ, 光 ファイバジャイロ，リングレーザジャイロなどが使われて いる．ジャイロの出力 (角速度)を積分することにより，あ る時点からの相対姿勢変化を検出することができるが，外 界センサではないので絶対姿勢は決まらず，また一般にジ ヤイロにはドリフトがあるので，長時間積分すると姿勢誤

†宇宙科学研究所 宇宙探査工学研究系

"Sensor Technology for Spacecraft" by Tatsuaki Hashimoto and Takashi Kubota (Spacecraft Engineering Division, The Institute of Space and Astronautical Science, Sagamihara)

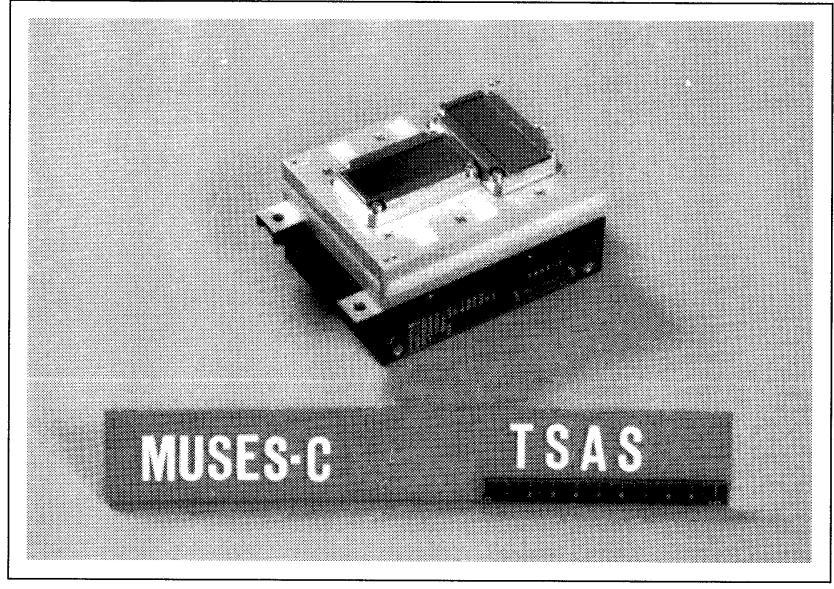

図 1 太陽センサの外観 (宇宙科学研究所提供)

差が大きくなる。したがって，後述の絶対姿勢を検出する センサとの組合せが必須である。

\section{2 慣性空間に対する絶対姿勢を検出するもの}

宇宙機搭載センサにより太陽や恒星の方向を検出できれ ば，それらの天体の慣性座標上での方向は既知であるので, 宇宙機の絶対姿勢を知ることができる，厳密には（特に太 陽の場合は), 宇宙機から見た天体の方向は宇宙機と天体 との相対位置にも依存するので，2.3項のセンサと同様に 姿勢と位置がカップルする。しかしながら，一般に検出し たい姿勢精度に比べて宇宙機と天体との相対位置は充分に 精度よく既知であるので，これらは絶対姿勢を検出するセ ンサとして使用することができる。

太陽は非常に明るい光源なので他の天体と間違う可能性 はなく，太陽センサ (図1) はロバストなセンサとして使用 することができる。ただし，日陰中（太陽が天体の㓌にな る夜の期間) は使用できない。また太陽センサのみでは太 陽方向まわりの姿勢が検出できないので，3軸姿勢を知る ためには他のセンサとの組合せが必要である.

一方恒星センサ (図2) は暗い星を検出対象とするので, 太陽光等の迷光の遮断, 検出素子の冷却等による $S / N$ の改 善, 検出素子のホットピクセルや放射線粒子痕等による偽 星の排除等の工夫が必要である. また，恒星は全天でたく さんあるので，七ンサで検出された星が星カ夕ログの中の どれであるかの対応 (星同定)をする必要があり，処理能力 の高い搭載計算機が必要であることから，本格的に使われ るようになったのは最近になってからである。恒星センサ は高精度に姿勢を検出することが可能であり，1台のセン サでは地球等の陰（地蝕と呼ぶ）になり，使えない期間があ 


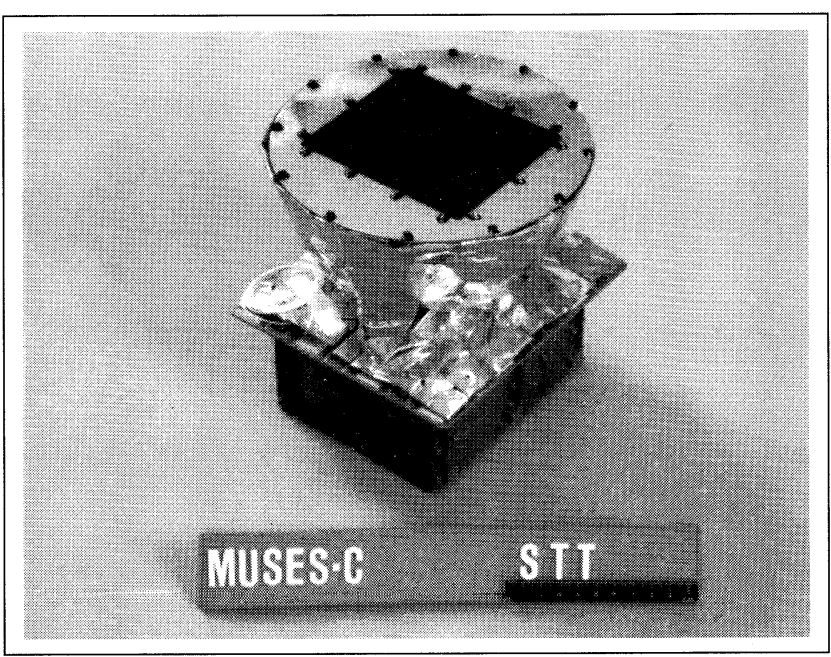

図2 恒星センサの外観（宇宙科学研究所提供）

るが，視野方向の異なる複数台のセンサを搭載することで 常に姿勢検出することが可能となる．また視野内に複数の 星を観測することができれば，一つのセンサで3軸の姿勢 を決定することが可能である。一般に暗い星を検出するた めには検出素子の露光時間を長くする必要があるので, そ の出力周波数は現状では $10 \mathrm{~Hz}$ 程度に限られている.

\section{3 地球 (惑星) 固定座標に対する姿勢を検出するもの}

地球周回の人工衛星の場合, 古くから地磁気センサと地 球センサ (赤外センサ) が使われてきた。地磁気センサとは 3軸方向に配置された磁力計であり，宇宙機の位置が既知 であればその場所での地磁気ベクトルの方向を測定するこ とにより宇宙機の姿勢を計測するものである. 地磁気セン サの欠点は，軌道位置精度が姿勢精度に影響すること，宇 宙機の搭載機器からの磁気干渉等によって精度が悪化する こと，高高度になると磁場が弱くなり使えないことなどが あり，主に地上にて事後に姿勢決定するような用途に使わ れてきた。

地球センサにはいろいろなタイプのものがあるが，基本 的には赤外線センサで地球のエッジをとらえ，それから地 心方向を検出するものである，低高度周回衛星で使用する 場合は軌道位置精度にも影響され，また地球の立体角が大 きくなるので精度よく検出するためには工夫が必要であ る。静止軌道のような高高度では比較的簡単に地心方向を 得ることができ，静止衛星にはよく使用されている，同様 に惑星周回探査機では，搭載カメラにより惑星を撮像する ことにより，惑星相対の姿勢を得ることができる.

これらのセンサを宇宙機上で使用するためには，機上で 逐次の軌道位置を計算する必要がある。一般には定期的に 軌道要素を地上からアップロードし，機上にて軌道伝搬計 算を行っているが，最近ではGPS受信機を搭載して自己位 置をリアルタイムに知ることも可能となっている，逆に， 宇宙機の姿勢が既知の場合，これらのセンサは軌道位置セ
ンサとして使用することもできる，惑星探查機では，搭載 カメラの画像と既知の地図とのマッチングにより, 探査機 位置を決定する研究もなされている.

\section{3. 宇宙機の姿勢決定法}

宇宙機の姿勢制御方式は，コマのように回転させて角運 動量保存則にて姿勢を慣性空間に固定させるスピン安定型 と，常に姿勢を検出してアクチュエータ（リアクションホ イールなどによって制御し続ける3軸姿勢制御方式に大別 できる.

スピン安定型の宇宙機の姿勢決定は，スピン軸の方向と スピンレート・スピン位相を決定することである，スピン 型の太陽センサはスピン軸に沿う方向に配置された1次元 のセンサで，太陽が視野に入った瞬間（スピン位相の原点） にパルスを出力するとともに，そのときにスピン軸と太陽 方向の間の角度を計測する。またパルスの間隔を計測する ことによりスピンレートが求められる，慣性座標上でのス ピン軸方向を決めるためには, 恒星センサ, 地磁気センサ, 地球センサなどもう一つのセンサが必要である。太陽セン サと地球センサを用いたスピン軸方向決定の例を図3に示 す。スピン軸は, 天球図上で両センサの出力角度 $\beta, \eta$ の 円を描いたときに，その交点として求めることができる. 一般に交点は二つあるが，その他の情報から予想される姿 勢に近い方を選択する，あるいは一方のセンサが地球セン サ，地磁気センサのように軌道位置に依存するセンサの場 合，正解でない方の交点は天空上を動くことになるので， 時系列デー夕を処理することにより正しいスピン軸方向を 決定できる。

3軸姿勢制御の宇宙機の場合は，IRUを用いて姿勢を積分 し，姿勢初期值の決定とIRUのドリフト補正のために外界 センサが使用される，外界センサとしては，要求精度が高

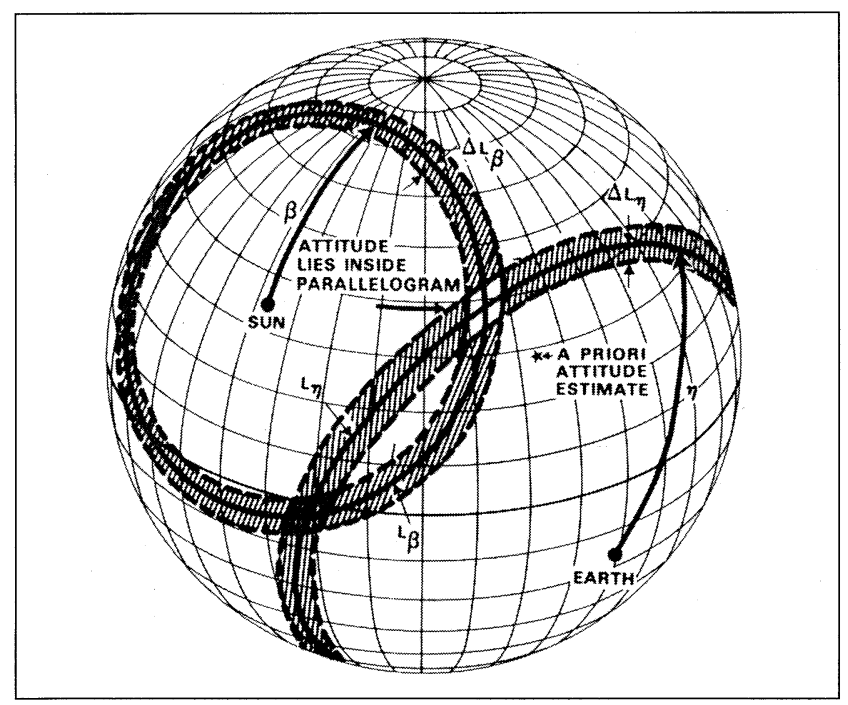

図3 スピン軸方向決定の例! 
くない場合は太陽センサ, 地球センサ, 地磁気センサなど が使用され，細密な姿勢決定には高精度型太陽センサ，恒 星センサが使用される，特に高精度の恒星センサは狭視野 となるので，星が少ない方向を向いた時にも視野内に必要 数の星の検出を保証するため, 6等星以下の暗い星を使用 する必要がある，そのため星同定の対象とする星の数は非 常に多くなり，探索領域を減らすために他のセンサによる 粗姿勢 (a priori姿勢) 決定が必要になる.

IRUと外界センサを組合せて高精度の姿勢決定を行うた め, 次式のような系についてノミナル值まわりで線形近似 した拡張カルマンフィルタが使用されている22.

(1) 状態遷移方程式

$\varepsilon(t+1)=F(t+1, t) \quad \varepsilon(t)+G(t) \mathbf{w}(t)$

$\varepsilon$ : 状態変数 (3軸姿勢角誤差, 3 軸IRUバイアス誤差)

$F:$ 状態遷移行列 (IRU出力の座標変換を考虑した皘分)

$G:$ 駆動行列 (IRU出力雑音と状態変数との関係式)

$\mathbf{w}$ : システム雑音 (IRU出力の雑音)

(2) 観測方程式

$\mathbf{Z}(t)=H(t) \varepsilon(t)+v(t)$

$\mathbf{Z}$ : 観測残差

$H$ : 観測行列 (状態変数と各センサ観測誤差の関係式)

$v$ : 観測雑音 (各センサの出力の雑音)

宇宙機の場合, 通常のカルマンフィルタのように真の姿 勢運動を状態力程式にすると，環境外乱，宇宙機の柔軟特 性，慣性特性の不確定性などの影響を受けてしまう。その ため, IRUのドリフトモデルを運動方程式にみたて，外界 センサによる姿勢検出を観測方程式としている．IRUの出 力誤差はシステム雑音として, 外界センサの検出誤差は観 測雑音として扱い, 各センサの姿勢決定に対する重みは誤 差共分散行列として設定される。この方式では, 外界セン サについては対応する観測行列および観測雑音の共分散を 設定するのみで，すべてのセンサを同等に扱うことができ る。また，外界センサが使用できない期間には観測更新が 行われないので，自動的にIRUのみで姿勢伝搬することに なる．複数の星が観測された場合は更新回数が多くなるの で, 観測誤差がランダムであれば観測数に応じて姿勢決定 精度が向上する。なお複数のセンサを用いて観測更新を行 う場合，セン㶾間の相対角度 (アライメント)に誤差がある と各センサの観測の度に姿勢決定值が振動的になる。した がって, アライメントの精度と観測䛊差共分散の設定值, 熱歪み等によるアライメントの変動時定数とフィルタの時 定数の関係などにも注意を払う必要がある。

\section{4. 惑星探査機の着陸航法センサ}

太陽系には，数多くの天体が存在する。それらの探査を 行うことは, 太陽系の成り立ちや生命の起源の解明などの 科学的な目的, 人類共通の知的資産の蓄積, そのための先 端技術の開拓・発展, 地球外資源の発掘などの実利用, さ
らには人類の活動範囲の拡大といった壮大な計画などさま ざまな利点が挙げられる. 惑星探査は, 惑星の地形などの 外観を調べる初期の偵察型から, 探査目的を絞って高精 度・高分解能を极らう探求型に移行している. 特に, 惑星 の詳細な探查を行うには, 惑星表面に着陸して直接的な移 動探査を行う手法が有効である.

目標地点に, 高精度でかつ安全確実に着陸するためには, 高度な航法誘導技術が必要である。特に深宇宙においては 地球との通信に時間がかかるため, 惑星への最終接近・着 陸では, 搭載コンピュータによる自律着陸航法誘導機能が 不可欠である. そのため, 探査機搭載センサを駆使して, 探査機の姿勢決定, 相対位置揖よび速度の検出, 惑星表面 の認識・障害物回避を精度よく行うことが重要である.

\section{1 小惑星探査機「はやぶさ」}

宇宙科学研究所は, 2003 年 5 月 9 日に近地球型小惑星 1998SF36へ向けてMUSES-C探査機「はやぶさ」を打ち上げ た. MUSES-Cミッション3)では, 世界で初めて小惑星のサ ンプルリターンを行う予定である. MUSES-C探査機は工 学試験衛星で, 電気推進, 自律航法誘導, サンプル採取, 回収カプセルリエントリなどの技術の検証を行う.

大きさも形状も未知の天体に接近・軟着陸するために は, 高度な航法誘導制御手法が必要となる. 探査機「はや ぶさ」に搭載された航法誘導姿勢制御センサを図4に示す. 姿勢検出には，慣性センサとして慣性基準装置 (IRU) を, 外界センサとして2次元太陽センサ（TSAS）とスタートラ ッカ (STT) を用いる。 セーフホールド時の太陽方向検出 のため, 粗太陽センサ (CSAS) を 5 基搭載する。また, 軌 道制御時の速度変化を検出するため，4基の加速度計 (ACM) を有する.

惑星との相対位置検出㧍よび小惑星表面への降下航法の ため, 望遠カメラ (ONC-T), 広角カメラ (ONC-W1, W2), レーザ測距計 (LIDAR, LRF)を用いる. LIDARは遠方域 での距離計測，LRFは近傍域での距離計測を行うＬRFは LRF-S1，LRF-S2を含む. LRF-S1は測距ビームを4本有し， 高度 $100 \mathrm{~m}$ 以近に扔いて表面距離ならびに傾斜を検出する。 LRF-S2は,サンプラが表面に接触したことを検知するため, サンプラ先端の変形を検出する，表面直近に扔いて，表面 上の障害物の太陽電池パドルとの衝突を避けるため, 障害 物検知センサ (FBS) を有する.

\section{2 小天体自律着陸}

着陸シーケンス ${ }^{4)}$ に匛じ用いる着陸航法誘導センサを 図5に示す。探査機は航法用カメラとレーザ高度計を用い て，小惑星近傍に滞在し，詳細なマッピングを行う。その 後, 画像と高度情報をもとに, 降下, 接近を行う。惑星 表面に近づいたら人工的な標的であるターゲットマーカを 放出し, 探查機と着陸地点との相対速度のキャンセルを行 う。ささらにマルチビームを有する近距離センサを用いて探 查機を地表面に平行になるように姿勢制御を行う。最終夕 


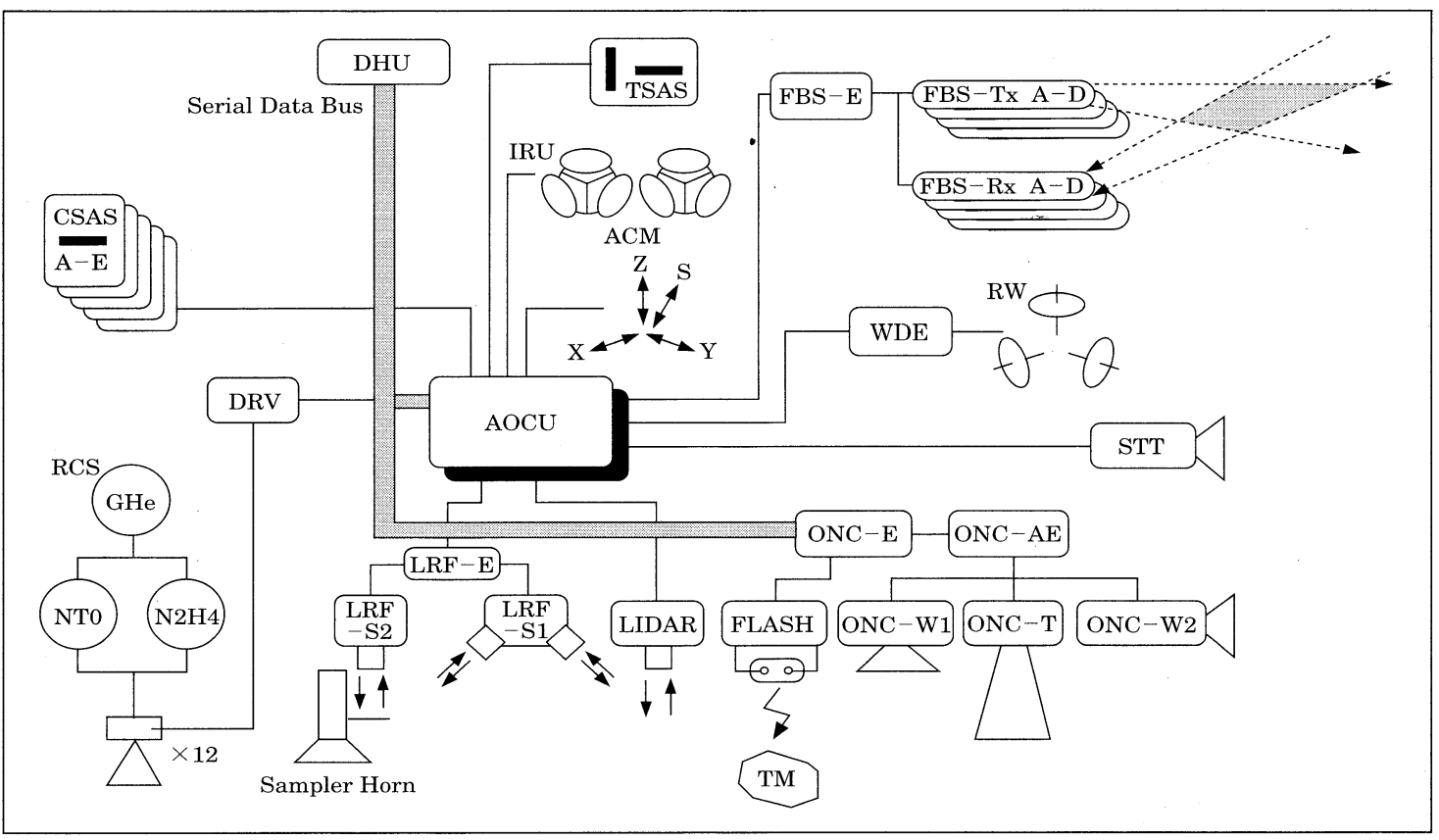

図4 小惑星探査機「はやß゙さ」に搭載されたセンサ

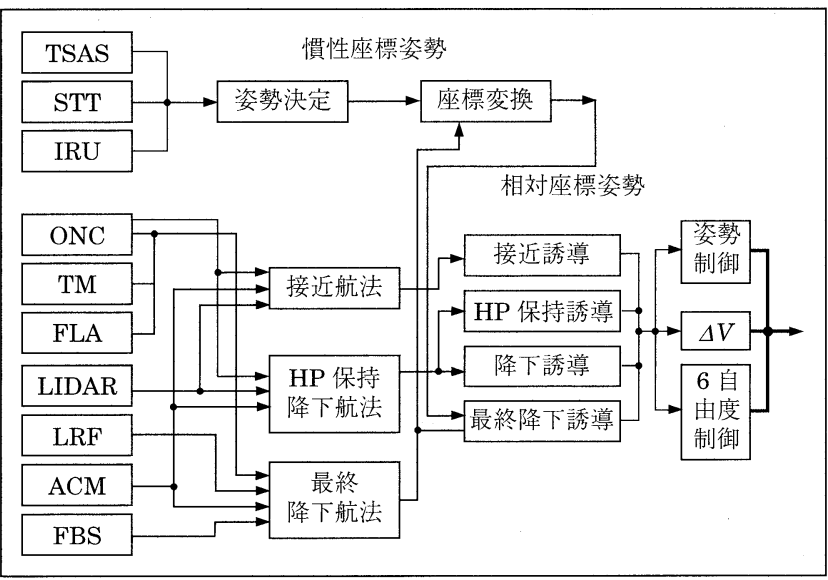

図 5 着陸航法誘導センサ

ッチダウンフェーズでは，衝突防止センサにより太陽パド ルなどの衝突を防止する．このように複数のセンサを組合 せることにより，探査機は安全に接近・着陸することが可 能となる.

\section{3 タッチダウン検出}

小惑星表面では，重力は小さく，着陸して保持するには， ジェットを逆方向に噴射するか，アンカーなど特別な固定 装置が必要になる。そのため, サンプラ装置にダンパ機能 をもたせ，小惑星表面に接触して離れるまでの短時間にサ ンプルを採取するタッチアンドゴー方式を採用している. 小惑星表面がどのような物質でできていようとも，サンプ ル採取を可能とするために，プロジェク夕を小惑星表面に 向けて高速に発射し，その衝撃で粉砕された破片をサンプ ラ装置で回収する。 そこで, 探查機の小惑星表面への接触

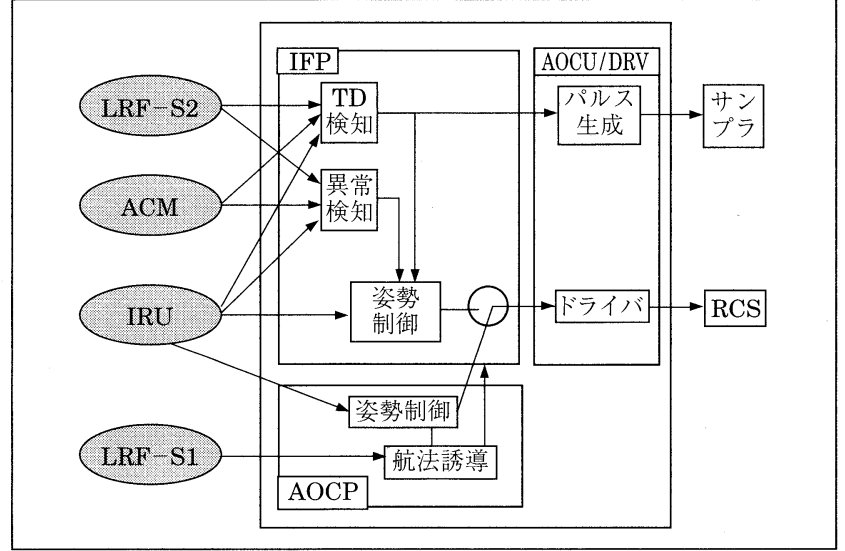

図 6 タッチダウン検出方法

を検知するために，図6に示すように，下記のセンサ情報 を組合せた方式を用いる。

（1）LRF-S2 の測距値ならびに受光量レベルの変動

(2) ACM計測による加速度変動

（3）IRU計測による姿勢角速度変動

\section{5. 探査ロボットのナビゲーション}

月や惑星を詳細にかつ広範囲にわたって探査を行うため には，移動ロボット（ローバ）による探查が必要となる．月 や火星の場合, 地球との通信時間が往復数秒から数十分か かる．また非可視運用や通信リンクの容量確保に要するコ ストなどから，遠隔操縦だけでは長距離ミッションは難し い。したがって，搭載センサを用いた障害物回避など知的 な判断を行う環境適応型の自律航法誘導手法が不可欠であ 
る、そこで各種センサを組合せて，信頼性の高い情報を得 ることが必要となっている.

\subsection{3 火星探査ローバ}

米国NASAは，2003年6月10日と7月7日にローバ2機5)を 火星に向けて打ち上げた．2機の探査機は，2004年1月に火 星の別々の場所に着陸し，水の痕跡をたどる．2003年のミ ッションでは，1997年に行われたマーズパスファインダミ ッション6) と同じく，パラシュートおよびエアバッグを用 いたシナリオで着陸を行う。

各ローバの重量は約 $180 \mathrm{~kg}$ ，ロッカボギーサスペンショ ンを有する6輪ローバ(図7)である。科学観測機器としては, 地形撮像用パノラマカメラ，熱放射分光計，Mossbauer分 光計, $a$ 線X線分光計, 近接カメラ, 岩石削磨ツールがあ る．火星に到着したローバは，まず $1.5 \mathrm{~m} の$ 高さに搭載され たステレオカメラにより，周囲の画像を撮影し，地球に送 る.科学者はこれらの画像から探査場所を決め, ローバに 伝える。この情報をもとにローバは1日で40mほど移動し， 90日間のミッションで，延べ $1 \mathrm{~km}$ 程度の移動探査を行う予 定である。

\section{2 ナビゲーション手法}

探查ロボットが目標観測地点に到達するためには，ロボ ット自体の惑星上での現在位置抢よび方位を知ることが必 要である．火星探查ローバ「ソジャーナ」は着陸機の周囲し か移動しないため，車輪の回転数を積分するデッドレコニ ングと着陸機からの画像に基づく位置修正によってローバ の自己位置が更新された。一方，2003年打ち上げた火星探 查ローバは，オンボード処理による自律ナビゲーション機 能を有している．前方拉よび後方に視野角 $120^{\circ}$ のステレ オカメラにより障害物回避を行う。また，長距離移動には 太陽センサと慣性航法センサにより自己位置同定を行う。

慣性航法による自己位置同定では，長距離移動すると誤 差が蓄積する。そこで，パノラマ画像から自己位置同定を 行う手法も研究されている7 . 取得したステレオ画像から エレベーションマップを作成し，全体的な基準マップと階 層セル分解アプローチに基づいて比較することにより位置 推定を行う，比較するのに一番良い既知の初期位置を決定 するため，デッドレコニングを行う。遠くにある既知の最 良位置より，良くマッチする位置を含んでいるかどうか各 セルを調べる。セルがそのような位置を含んでいなければ さらに探索する。含んでいればサブセルに分けて，帰納的 にプロセスを繰り返す。ある程度精密なレベルまで進めば プロセスを終了し，セルの中央位置が明白に最良既知位置 だと決定できるかを調べる。なお，基準マップとしては周 回軌道上や降下フェーズで撮像した画像を用いる.

そのほかの手法として，太陽位置情報と3次元地形情報 を用いて自己位置を推定する手法8)も提案されている．惑 星上の扮招まかな絶対位置・方位は，太陽の位置を観測す ることにより求める。一方，ローバが移動するとき，相対

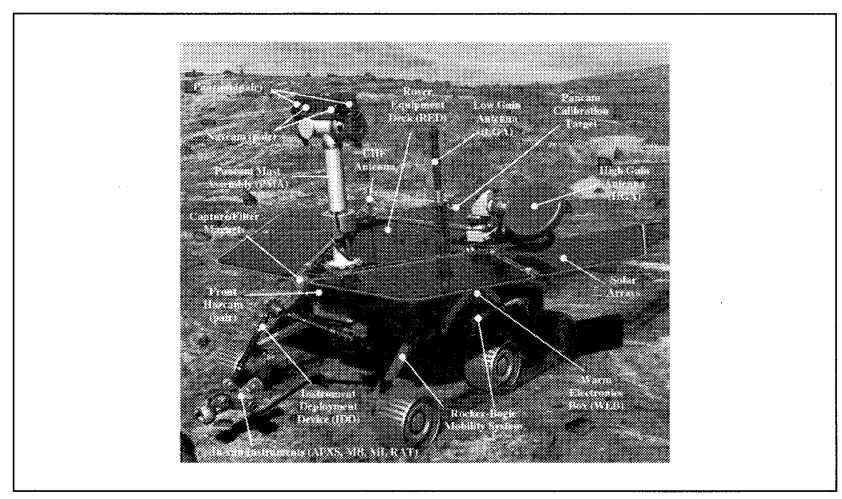

図7 火星探査口ーバ5)（NASA/JPL/Caltech）

的な位置推定にマップマッチング法を用いる。また移動中 の地図デー夕とあらかじめ得られている惑星の地形デー夕 を照合することにより，詳細な自己位置同定を行う。

このように, 画像デー夕, 慣性センサデー夕, 地図デー 夕を融合して，精度のよい位置情報を得る。

\section{6.むす び}

人工衛星，宇宙探査機，宇宙探査ロボットで用いられて いるセンサ技術について紹介した。宇宙機システムでは， 重量と電力の厳しい中で，多種類のセンサを組合せて，精 度のよい，信頼性の高い情報を構築することが重要である. ミッションが高度化するにつれて，センサフュージョンを 含むセンサ情報処理の役割はますます大きい.

(2003年7月29日受付)

\section{〔文 献〕}

1) J.R.Wertz: "Spacecraft Attitude Determination and Control", Kluwer Academic Publishers (1980)

2）二宮ほか：“X線天文観測科学衛星「あすか」および「ASTRO-E」の 姿勢制御系”，宇宙科学研究所報告第121号（Mar. 2003）

3) http://www.isas.ac.jp/

4) T.Kubota, et al. : "An Autonomous Navigation and Guidance System for MUSES-C Asteroid Landing”, Acta Astronautica, 52, pp.125-131 (2003)

5) http://www.jpl.nasa.gov/mer/

6) http://mpfwww.jpl.nasa.gov/

7) http://nmp.jpl.nasa.gov/fido/

8）中谷，久保田：“深宇宙探査機の自律化技術”，計測と制御，39，9, pp.570-575 (2000)
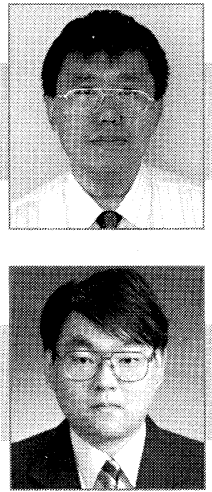

簥昆本 樹明 1990 年, 東京大学大学院工学系研 究科電気工学専攻博士課程修了. 同年, 宇宙科学研 究所入所. 1995年, 助教授. 1999年, 米国NASA シ エット推進研究所客員科学者. 人工衛星の姿勢制御, 惑星探査機の画像を用いた航法, 搭載センサ開発等 の研究および大学院教育に従事. 工学博士.

久保甾 踍 1991 年, 東京大学大学院工学系研 究科博士課程修了. その後, 富士通研究所研究員を 経て, 現在, 文部科学省宇宙科学研究所宇宙探査工 学研究系助教授. 1997年 1998年, 米国NASAジェ ット推進研究所客員科学者. 惑星探査ロボット, 自 律航法誘導, 宇宙人工知能の研究に従事. 工学博士. 